\title{
MENGKAJI TRADISI NABI SEBAGAI PARADIGMA DAKWAH YANG RAMAH
}

\author{
Faiqotul Mala \\ Institut Agama Islam Syarifuddin Lumajang \\ Email: faiqo.mala@gmail.com
}

\section{ABSTRACT}

Artikel ini membahas tentang karakteristik dakwah Nabi Muhammad. Diskusi mengenai dakwah yang penuh perdamaian adalah penting. Apalagi, belakangan ini, marak pemberitaan tentang ISIS (Islamic State of Iraq dan Syria), khususnya tentang isu rencana pemulangan eks ISIS ke Indonesia yang menimbulkan pro dan kontra di antara beberapa kalangan. Kendatipun pada akhirnya pemerintah memutuskan untuk tidak memulangkan eks ISIS lintas negara kembali ke Indonesia, namun hal ini sangat mengancam keamanan dan menimbulkan keresahan dan kekhawatiran di tengah masyarakat. Nabi Muhammad adalah teladan bagi para dai dalam menyebarkan nilai-nilai Islam yang rahmatan lil alamin, dengan penuh kegigihan, rendah hati, dan kesabaran. Dakwah dengan penyampaian yang lemah lembut, dan ramah terhadap realitas sosial yang ada, merupakan ajaran Nabi yang berpijak pada wahyu Allah. Oleh karena itu, para pendakwah tidak hanya dituntut mempelajari sumber-sumber ajaran lalam, tetapi juga harus memahaminya secara komprehensif melalui berbagai disiplin ilmu yang kemudian diintegrasikan dengan karakter dan kondisi sosial masyarakat. Jika dakwah disampaikan dengan cara anarkis atau kasar, hal itu menunjukkan bahwa minimnya pengetahuan dan penghayatan tentang ajaran Islam. Karena sejatinya tidak ada satu agama pun di dunia ini yang melegalkan atau mengajarkan tindakan anarkis. Agama Islam justru menjadi sumber utama inspirasi kebahagiaan dan kedamaian.

Keywords: Dakwah, Damai, ISIS, Rahmatan lil alamin

\section{PENDAHULUAN}

Belakangan ini tengah marak pemberitaan tentang ISIS (Islamic State of Iraq dan Syria), khususnya tentang isu rencana pemulangan eks ISIS ke Indonesia yang menimbulkan pro dan kontra di antara beberapa kalangan. Kendatipun pada akhirnya pemerintah memutuskan untuk tidak memulangkan eks ISIS lintas negara kembali ke Indonesia, namun hal ini sangat mengancam keamanan dan menimbulkan keresahan dan kekhawatiran di tengah masyarakat. Cepat atau lambat jika aksi-aksi terorisme, radikalisme, dan anarkisme atas nama agama tidak diantisipasi oleh pemerintah, maka tanpa kita sadari mereka bisa saja masih berusaha untuk membangun kekuatan secara masif. Pemahaman merekapun akan meluas menjadi gerakan yang membahayakan. Apalagi bila itu merasuk dalam pikiran dan jiwa generasi muda. 
Ideologi yang mereka bawa terus-menerus menyebarkan ekstremisme, radikalisme, dan terorisme. Dunia maya dijadikan sarana untuk merubah pola fikir masyarakat. Sedangakan pemahaman mereka cenderung menghalalkan bertindak anarkis dengan menggunakan kekerasan sebagai jalan pintas tanpa toleransi. Sering kita temui bahwa karakter dakwah yang dilakukan oleh kelompok ekstremisme hanya mengandalkan suara yang lantang, lilitan sorban, dan hentakan takbir. Khutbah atau kajian di masjid yang seharusnya dilaksanakan dengan khidmat dan berisi hikmah serta mauidzah hasanah, malah diisi dengan ceramah yang bersifat provokatif demi kepentingan-kepentingan tertentu. Panggung-panggung keagamaan yang seharusnya digunakan untuk menebar ajaran Islam, disalahgunakan untuk kepentingan politik praktis yang sifatnya sementara.

Tidak hanya di masjid, kini di berbagai perguruan tinggi negeri dan swasta menjadikan mahasiswa-mahasiswa baru sebagai sasaran utama kelompok radikal ini. Dari pintu ke pintu, dari kelas ke kelas, mereka selalu mengajak untuk bergabung. Mahasiswa baru yang masih dangkal pemahaman agamanya, dengan terpkasa dan tanpa sadar akhirnya bergabung dan menjadi bagian dari kelompok radikal. Lambat tapi pasti, akhirnya para mahasiswa tersebut memahami dan mengamini ideologi radikal yang dibawa oleh kelompok ini. Mereka juga percaya bahwa hukum "jihad" adalah wajib dan pelakunya pasti akan masuk surga. Merekapun pada akhirnya meyakini dan menganggap bahwa Umat Islam yang tidak sejalan dengan mereka dilabeli dengan "kafir".

Hal ini kemudian menyebabkan adanya klaim bahwa Islam identik dengan kekerasan atau teroris identik dengan Islam. Anggapan itu seakan-akan menemukan pembenarannya setelah melihat aksi-aksi persekusi yang dilakukan oleh oknum orang Islam sendiri. Mulai dengan aksi teror sampai persekusi semakin mengukuhkan tuduhan orang luar, bahwa Islam tidak jauh dari tema-tema kekerasan. Namun, apakah benar bahwa dalam ajaran Islam ada perintah untuk melakukan tindak kekerasan dengan cara teror? Apakah benar jihad yang menjadi landasan mereka untuk berbuat anarkis itu, sesuai dengan jihad yang sudah dicontohkan oleh Nabi Muhammad S.a.w?

\section{PEMBAHASAN}

Nabi Muhammad SAW di pilih oleh Allah sebagai manusia yang paling agung dan paling berpengaruh sepanjang sejarah umat manusia. Sebagai Nabi terakhir sekaligus rasul yang diangkat pada tanggal 17 Ramadhan pada usia 40 tahun, banyak sekali kebiasaan Nabi 
yang bisa kita teladani. Kebaikan, ketaqwaan, keikhlasan, dan akhlak Nabi dalam membimbing umatnya menimbulkan simpati yang berkesan sehingga apa yang disampaikan mudah diterima. Beliau mempunyai karakter tersendiri dalam menyampaikan dakwahnya, dan itu menjadi kunci kesuksesan dakwah beliau. Beberapa karakter tersebut diantaranya sebagai berikut:

\section{Selalu menyamakan antara perkataan dan perbuatan}

Nabi tidak pernah membedakan apa yang beliau katakan dengan apa yang beliau kerjakan. Hal ini berarti bahwa segala sesuatu yang diperintahkan oleh Nabi pada sahabatnya, beliau juga mengerjakannya. Antara perkataan dan perbuatan selalu disamakan sehingga memudahkan para sahabat untuk memahami dan melaksanakan perintah Nabi karena melihat langsung contoh praktek dari perintah tersebut. Misalnya ketika beliau mengatakan "shalatlah kalian seperti kalian melihat aku salat". Selain itu untuk masalah yang berkaitan dengan perempuan beliau memerintahkan namun tidak mengerjakan, sebagai gantinya beliau menyusuh istrinya unutk memberikan contoh langsung. Hal ini tergambar dalam sebuah riwayat ketika seorang wanita Ansor yang datang bertanya tentang bagaimana membersihkan bekas darah haid, beliau kemudian mengatakan "ambillah kain yang empuk kemudian tekan lah kain itu”. Wanita Anshar tersebut tidak bisa langsung memahami perintah Nabi, kemudian istri beliau Siti Aisyah mengajak wanita itu masuk kamar dan menerangkan dengan jelas bagaimana membersihkan bekas darah haid ${ }^{2}$.

Cara berdakwah seperti ini tidak semua para pendakwah zaman sekarang bisa melakukannya. Apa yang mereka ucapkan dan yang mereka perintahkan kepada para jemaah terkadang tidak sesuai dengan apa yang mereka lakukan. Sementara hal ini sebenarnya juga sangat di dikecam oleh Allah sebagaimana dalam firman-nya (QS. Shoff, 2-3)

\footnotetext{
${ }^{1}$ Muhammad bin Ismail Al Bukhari, Shahih al-Bukhari (Singapore: Sulaiman mar'e, tth), I/117

2 Muhammad Ali al-Shobuni, Rawa'i Al Bayan tafsir ayat Al Ahkam Min Al-quran (Damaskus: Maktabah Al Ghazali, 1977 M), I/319
} 


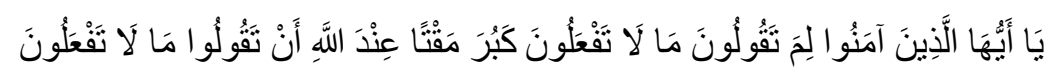

Wahai orang-orang yang beriman, kenapakah kamu mengatakan sesuatu yang tidak kamu kerjakan? Amat besar kebencian di sisi Allah bahwa kamu mengatakan apa-apa yang tidak kamu kerjakan

Kata dakwah berarti mengajak, bukan hanya memberi pemahaman. Jadi seharusnya para da'i tidak cukup hanya menyampaikan dakwah, namun ia harus memberi contoh (uswah) terlebih dulu sebelum ia menyampaikan dan menyuruh orang lain. Sebagaimana Nabi yang selalu membangun kedekatan dan kesetaraan dengan orang yang didakwahi. Hal itu tergambar dari kebiasaan beliau yang selalu menyebutkan semua yang hadir dalam majlis Nabi mereka semua adalah shahabatnya. Sehingga tampak tidak ada sekat antara Nabi sebagai da'i dengan sahabat sebagai orang yang didakwahi. Selain itu dakwah harus berdasarkan argumentasi yang selalu mengedepankan bahasa dam pemahaman universal yang bisa diterima masyarakat luas. Mencari titik temu dari perbedaan pendapat, mengajak ummatnya untuk berfikir. Misalnya dengan menjelaskan alasan mengapa hukum ini halal, dan mengapa diharamkan. Dengan demikian akan tampak suasana kesetaraan yang tidak menggurui tapi menunjukkan. Inilah kunci mengapa dakwah Nabi berhasil, dikarenakan ada konsistensi dengan etika yang selalu diterapkan oleh Nabi dan juga uswah keteladanan yang selalu dicontohkan oleh Nabi.

\section{Nabi tidak menyampaikan hal yang tidak diketahui}

Selama proses berdakwah Nabi hanya menyampaikan materi berdasarkan ilmu yang dikuasai. Sedangkan materi yang tidak beliau ketahui atau tidak kuasai tidak akan beliau sampaikan. Seperti halnya ketika seorang sahabat menanyakan tentang pertanian yang berkaitan dengan penyilangan pohon kurma beliau menjawab "kamu lebih tahu tentang urusan (pertanian) kamu"3. Jawaban Nabi ini menunjukkan bahwa beliau memasrahkan sepenuhnya kepada para sahabat yang memang ahli di bidangnya.

Hal ini yang juga perlu diperhatikan oleh para pendakwah. Terlebih jika dia menyampaikan suatu hukum antara halal dan haram, maka seyogyanya ia telah tahu persis dan detil tentang hukum tersebut. Jika memang dia tidak mengetahui, lebih baik dia mengatakan wallahualam atau meminta maaf untuk tidak menjawab langsung dan

\footnotetext{
${ }^{3}$ Muslim ibn al-H\{ajja>j ibn Muslim al-Naisa>buri>, S\{ah\{ih\{ Muslim (Bairu>t: Da>r al-Ih\{ya>' al'Arabi>, tth), I/80.
} 
diberikan waktu untuk mencari jawabannya. Jadi sebagai seorang da'i tidak dibenarkan untuk asal-asalan menjawab karena bisa jadi akan menyesatkan orang lain. Sedangkan masalah yang sering ditanyakan kepada seorang da'i tentu masalah keagamaan yang harus jelas dalilnya4 ${ }^{4}$ Sebagaimana yang Allah tegaskan dalam Alquran surat al-Isra ayat 36

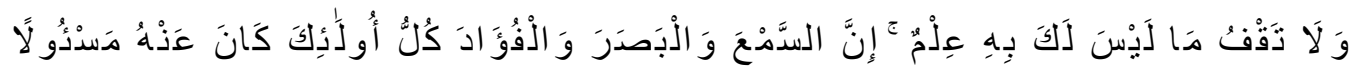

Dan janganlah kamu mengikuti apa yang kamu tidak mempunyai pengetahuan tentangnya. Sesungguhnya pendengaran, penglihatan dan hati, semuanya itu akan diminta pertanggungan jawabnya.

Dari ayat ini dapat disimpulkan bahwa validitas informasi dalam berdakwah adalah hal yang sangat krusial dan harus menjadi perhatian utama para penerus dakwah Rasulullah S.a.w. Hal inilah yang kemudian menjadikan tradisi sanad dalam ilmu hadis, khususnya ilmu periwayatan hadis, menjadi sangat penting.

Jika dilihat dari sisi historisitasnya, hadis telah berlangsung sejalan dengan perjalanan ajaran Islam sejak Rasulullah berdakwah yang pada akhirnya hadis tersebut sampai pada kita melalui rantai periwayatan, atau yang biasa disebut dengan sanad. Ada beberapa faktor yang menyebabkan kajian sanad sangat penting dilakukan. Di antaranya, karena pada zaman Nabi tidak seluruh hadis ditulis. Sering terjadi pemalsuan hadis sesudah zaman Nabi dan karena pembukuan hadis secara resmi terjadi setelah berkembangnya pemalsuan hadis. 5 Terkait dengan pentingnya kedudukan sanad, 'Abdullah ibn Muba>rak menyatakan andaikan sanad tidak ada, niscaya siapa saja akan menyatakan apa yang mereka kehendaki. ${ }^{6}$ Ima>m Nawawi> juga menjelaskan bahwa jika kualitas sanad suatu hadis sahih, maka hadis itu dapat diterima. Jika sanadnya tidak sahih maka hadis tersebut ditinggalkan. la juga menegaskan bahwa hubungan hadis dengan sanadnya bagaikan hewan dan kakinya. ${ }^{7}$

\footnotetext{
${ }^{4}$ Ali Mustafa Yaqub, Sejarah dan Metode Dakwah Nabi (Pejaten: Pustaka Firdaus, 2000) 47.

${ }^{5} \mathrm{Muh}\{\mathrm{ammad}$ 'Aja $>\mathrm{j}$ al-Khati $>\mathrm{b}, U s\{u>l$ al-Hadi $>$ th 'Ulu $>$ muhu wa Mus $\}$ t $\} a l a>h\{$ uhu ( Bairu>t: Da>r al-Fikr, 1975), 67.

${ }^{6}$ Dikutip oleh 'Abu> al-H\{usain Muslim ibn al-H\{ajja $>$ j ibn Muslim al-Naisa $>$ buri $>, S\{a h\{$ ih\{ Muslim (Bairu>t: Da>r al-Ih\{ya>' al-'Arabi>, tth), 14.

${ }^{7}$ 'Abu> Zakariya $>$ al-Nawa>wi>, Syarh $\{$ al-Nawa $>$ wi $>$ 'Ala $>S\{a h\{i>h\{$ Muslim (Mesir: al-Maktabah al-Mis \{riyyah, 1924), juz 1, 88.
} 
Isnad muncul pertama kali pada masa Nabi hidup, dimulai dari praktek para sahabat dalam meriwayatkan hadis Nabi ketika mereka saling bertemu. secara bergantian dan saling menginformasikan mengenai apa yang telah mereka dengar, dan biasanya dalam proses menginformasikan pada sahabat yang lain mereka menggunakan kalimat seperti Nabi telah melakukan ini dan itu. metode ini digunakan pada masa-masa awal untuk menyebarkan hadis Nabi dan inilah asal muasal sistem isnad. Sistem kemudian berkembang menjadi ilmu yang matang sehingga keberadaannya menjadi sangat penting terlebih ketika terjadi pergolakan politik yang pada waktu itu tidak bisa terhindarkan. yang menimbulkan adanya pemalsuan hadis pada periode tersebut. Oleh karena itu para ulama menjadi lebih hati-hati dan mulai meneliti sumber-sumber informasi yang mereka dapatkan.

Proses penyampaian ini tidaklah mudah karena para sahabat atau para parawi tinggal di tempat yang berbeda-beda. Sehingga seringkali para ulama abad pertengahan melakukan perjalanan panjang dengan harapan akan menemukan beberapa hadis baru yang dipercaya, dan untuk belajar pada seorang ulama hadis yang termasyhur di suatu daerah. Sedangkan guru tersebut juga mendapatkan hadis dari guru lain. Demikian seterusnya sehingga membentuk serangkaian perawi, dimana setiap generasi menambahkan anggota atau perawi baru dan kemudian terbentuk daftar panjang perawi hadis. Setiap perawi dikaitkan dengan guru sebelumnya yang pada akhirnya dikaitkan sampai pada Nabi. ${ }^{8}$ Hal ini dilakukan demi mempertahankan mata rantai periwayatan yang benar-benar berasal dari Nabi. Oleh karena itu, Kegiatan penelusuran hadis sampai pada sumber aslinya tidaklah mudah karena hadis terhimpun dalam banyak kitab, karenanya terdapat hal-hal yang harus diteliti dan diperhatikan diantaranya:

a. Meneliti profil perowi mulai dari biografi hidupnya, temapat tanggal lahir dan wafatnya, dan silsilah keturunan keluarga dan guru-gurunya. Hal ini perlu diketahui untuk melihat seperti apa sosok latar belakang seorang perawi. Selain itu hal yang harus diteliti adalah pribadi perawi secara detail. Dalam hal ini ulama sependapat bahwa ada dua hal yang harus diteliti dari pribadi perawi yaitu ke-'adil-an dan ke-d\{a>bit\{-annya. Kalau ke-'adilan berkaitan dengan kualitas pribadi sedangkan ke- $d\{a>b i t\{-a n$ berkaitan dengan kapasitas

\footnotetext{
${ }^{8}$ Annemarie Schimmeel, Dan Muhammad adalah Utusan Allah ( Bandung: Mizan, 2000), 47.
} 
intelektualnya. Apabila kedua hal tersebut dimiliki oleh perawi, maka perawi tersebut dapat dikatakan sebagai perawi yang thi>qah. ${ }^{9}$

b. Melihat kritik ulama lain atas kualitas pribadi perawi. Pengetahuan ini sangat penting dalam melakukan penelitian suatu hadis. Ulama yang ahli di bidang kritik perawi hadis jumlahnya relatif sedikit, karena tidak semua dapat memenuhi syarat untuk menjadi kritikus hadis. ${ }^{10}$. Dalam mengemukakan kritikan, ulama ahli kritik ada yang bersikap ketat (mutashaddid), ada yang longgar (mutasahhil), dan ada yang bersikap moderat (mutawassit \{)$^{11}$

c. Melihat metode periwayatan dan persambungan sanad. Bersambung atau tidaknya sanad hadis bisa dilihat dari metode yang digunakan dalam periwayatan hadis. Untuk itu dalam susunan sanad hadis selain memuat nama-nama perawi, juga memuat lafaz-lafaz yang memberi petunjuk tentang metode periwayatan yang digunakan masing-masing perawi. Dari lafaz-lafaz tersebut dapat dilihat tingkat akurasi metode periwayatan. Semua metode periwayatan ini sangat berpengaruh pada penelitian hadis, karena metode inilah yang menentukan apakah hadis yang diteliti benar-benar bersambung sampai pada Nabi atau tidak.

4. mengemukakan kesimpulan dari penelitian sanad yang disertai dengan argumenargumen yang jelas. Kesimpulan yang diambil biasanya berisi status hadis apakah kualitas hadis sahih, hasan atau lemah. Dengan demikian, sanad hadis memiliki peran yang sangat penting dalam meneliti suatu hadis. Karena jika suatu berita dinyatakan sebagai hadis oleh seseorang, tapi berita itu tidak memiliki sanad maka tidak bisa disebut hadis. ${ }^{12}$ Oleh karena itu peran sanad yang begitu sentral akan dapat menentukan mana hadis yang benar-benar datang dari Nabi dan mana yang bukan.

${ }^{9}$ Gabungan sifat ' $a>$ dil dan dhabit yang dimiliki seorang perawi. Lihat di $\mathrm{Nu}>\mathrm{r}$ al-Di $>\mathrm{n}$ 'Itr, Manhaj alNaqd fi 'Ulu>m al-Hadi>th (Damaskus: Da>r al-Fikr, 1399 H), 80-81. Muh\{ammad 'Aja $>$ j al-Khati>b, Usu>l al-Hadi>th 'Ulu>muhu wa Mus\{t\{ala>h\{uhu, 305.

${ }^{10}$. Syarat-syarat tersebut ada yang berhubungan dengan sikap pribadi yaitu seperti bersifat adil, tidak bersikap fanatik terhadap aliran atau mazhab tertentu, tidak bermusuhan dengan perawi yang dinilainya. Ada juga syarat yang berhubungan dengan penguasaan pengetahuan. Seperti memiliki pengetahuan luas berkenaan dengan ajaran Islam, menguasai bahasa Arab, hadis dan ilmu hadis, mengetahui jelas sifat, profil, latar balakang perawi yang dikritiknya 'Abd al-Rahman ibn 'Abi $>\mathrm{Ha}>\operatorname{tim}$ 'Abu> Muh\{ammad al-Ra>zi>, Al-Jarh\} wa al-Ta'di $>l$ (Bairu>t: Da>r al-Fikr, tth), 12. Muh\{ammad 'Aja>j al-Khati>b, Us\{u>l al-Hadi>th 'Ulu>muhu wa Mus\}t\}ala>h\{uhu, 267

${ }^{11}$ Muh $\{$ ammad ibn Ah\{mad ibn 'Uthma>n al-Dhahabi>, Dhikru Man Yu’tamad Qauluhu fi al-Jarh\{ wa al-Ta'di $>l$ (Kairo: al-Matbu'ah al-Islamiyyah, tth), 159.

${ }^{12}$ M. Syuhudi Ismail, Metodologi Penelitian Hadis Nabi (Jakarta: Bulan Bintang, 2007), 21. 
Itulah sebagian dari banyak cara yang diterapkan para ulama dahulu untuk menguji validitas hadis secara rasional. Sistem periwayatan hadis dijadikan sebagai acuan dalam mencari informasi. Proses periwayatan hadits yang dipaparkan di atas menunjukkan bahwa dalam menerima suatu informasi para sahabat sangat berhati-hati dengan berusaha mencari tahu asal muasal informasi itu secara valid; dari siapa berita itu didapatkan, siapa yang memberikan atau menyebarkan berita, apakah yang menyampaikan berita tersebut termasuk orang yang dapat dipercaya atau orang yang suka berbohong, dan bagaimana proses penyampaian berita itu. Semua harus diketahui dan diselidiki dengan pasti. Sehingga berita tersebut bisa dipertanggungjawabkan dan diterima sebagai informasi yang benar atau sebagai landasan yang otentik.

Hal ini secara tidak langsung memberikan contoh pada kita semua untuk selalu mengkonfirmasi setiap informasi yang kita terima. Kita tidak bisa asal-asalan menerima dan menyebarkan informasi tanpa mengetahui dari mana informasi itu didapatkan dan siapa yang mengatakan. Pada zaman yang serba canggih seperti saat ini, informasi mudah sekali didapatkan, sehingga kita mengenyampingkan kebenaran dari informasi tersebut. Kita terbaisa serta merta mengcopy paste dari Internet dan langsung meneruskannya ke sbuah grup WhatsApp (WA), tanpa mengkroscek benar atau tidaknya informasi tersebut. Sementara, jika ternyata informasi itu tidak benar adanya maka dampaknya akan sangat besar dan dapat menyebabkan kesalahpahaman, fitnah, dan perpecahan. Hal inilah yang perlu dihindari oleh kita semua, khususnya para da'i. Jika seorang da'l sudah terbiasa memberikan argumen, dalil, data hanya dari hasil copy paste, maka secara tidak langsung dia telah menyesatkan orang banyak.

\section{Menyesuaikan materi dan metode dakwah dengan konteks.}

Dalam menyampaikan dakwah sepatutnya hal yang harus diperhatikan oleh para da'i adalah ia tidak hanya mengerti teks tapi juga konteks dan karakter audiennya. Sebagaimana Nabi ketika berdakwah di kota Mekah dan Madinah yang tentunya berdasarkan strategi yang matang. Misalnya ketika di Mekah dalam proses mendakwahkan ajaran Islam tersebut Nabi mendapat tantangan yang berat dan menyakitkan. Dikarenakan Kultur masyarakat pada waktu itu menganut keyakinan 
Paganisme. ${ }^{13}$ warisan turun temurun dari kakek buyutnya di zaman Arab Jahiliyah. Keyakinan yang sudah kuat dan mengakar di kalangan masyarakat Mekah tersebut, menyebabkan dakwah Nabi selalu mendapat tantangan dari orang-orang kafir dan ahli kitab. Mereka sering menghina, dan berlaku buruk bahkan mengusir Nabi.

Tujuan dakwah Rasulullah SAW pada periode Mekah adalah agar masyarakat Arab mampu meninggalkan kejahiliyannya dalam bidang agama, moral dan hukum, sehingga menjadi umat yang mempercayai kebenaran ajaran Islam sekaligus agar dapat mengamalkannya dalam kehidupan sehari-hari. Demi tercapainya tujuan-tujuan tersebut, maka Nabi menerapkan strategi dakwah dengan cara sembunyi-sembunyi, selanjutnya dengan terang-terangan secara lisan, misalnya memberi nasehat, memberi peringatan dan sebagainya.

Dakwah tersebut berlangsung selama 3 tahun dimulai sejak tahun ke-4 kenabian, dan ketika turun wahyu yang berisi perintah agar dakwah itu dilaksanakan secara terangterangan sebagaimana dijelaskan dalam QS. Al-Hijr ayat 94: "maka sampaikanlah (Muhammad) secara terang-terangan segala apa yang diperintahkan (kepadamu) dan berpalinglah dari orang yang musyrik". Sejak itulah, Nabi mulai menyampaikan dakwah secara terbuka. Menariknya, selama tiga tahun berdakwah, hanya empat orang pengikut yang masuk Islam. Di antaranya adalah istri Nabi Muhammad Khadijah, dari keluarganya adalah 'Alī bin Abi Ṭalib, sedangkan dari kalangan budak adalah Zaid bin Haritsah, dan dari kalangan kerabat dekatnya Abu Bakar as-Siddīq, dimana mereka merupakan kalangan yang paling kecewa terhadap pergeseran moral dan sosial di Mekah, dan mereka membuktikan pesan-pesan Nabi Muhammad saw sebagai sebuah alternatif. ${ }^{14}$ Dalam proses dakwah secara terang-terangan ini, Nabi membagi dua tahap, pertama mengundang kaum kerabat keturunan dari Bani Hasyim untuk menghadiri jamuan makan sekaligus mengajak agar masuk Islam. Sedangkan tahap selanjutnya Rasulullah SAW mengumpulkan para penduduk Mekah untuk berkumpul di bukit shofa.

Sementara ketika di Madinah, dakwah Nabi dianggap sebagai kelahiran baru agama Islam setelah ruang dakwah di Mekah terasa sempit bagi kaum Muslimin. Allah SWT memilih Madinah sebagai pembentukan masyarakat Islam pertama dikarenakan Madinah

\footnotetext{
${ }^{13}$ suatu kepercayaan spiritual, atau praktek penyembahan terhadap patung dan berhala.

${ }^{14}$ Ira Lapidus, A History of Islamic Sicieries, diterjemahkan oleh Ghufron A. Mas'adi, dengan judul “Sejarah Sosial Ummat Islam”, (Jakarta: Raja Grafindo, 1999) 34-35.
} 
memang layak dijadikan kawasan percontohan. ${ }^{15}$ Berawal dari respon orang-orang Yastrib yang datang ke Mekah pada bulan haji terhadap seruan Nabi, juga tidak terlepas dari pribadi Nabi yang dikenal sebagai orang yang tak pernah berbohong. Keberhasilan dakwah Nabi dapat dilihat pada sikap orang-orang Yastrib di perjanjian Aqabah I dan II, dimana mereka mau mengubah sikap dan perilaku mereka, bahkan bersedia menjadi pelindung $\mathrm{Nabi}^{16}$

Inilah yang dilakukan Nabi terhadap masyarakat Yastrib, membentuk suatu masyarakat baru, dan meletakkan dasar-dasar untuk suatu masyarakat yang besar. Demi mewujudkan semua ini, Nabi menempuh langkah-langkah dakwah sebagai berikut:

Pertama: Membangun masjid. beliau membangun Masjid Nabawi pada sebuah tanah milik kedua anak yatim, tanah itu dibeli oleh Nabi untuk pembangunan masjid, juga untuk tempat tinggal. Masjid yang di bangun tersebut berfungsi sebagai tempat melaksanakan ibadah shalat. Dalam kesempatan ini Nabi dan para pengikutnya saling tolong menolong menanamkan semangat persaudaraan ${ }^{17}$. Masjid juga sebagai tempat untuk mempersatukan kaum Muslimin dan mempertalikan jiwa mereka, di samping sebagai tempat bermusyawarah merundingkan masalah-masalah yang dihadapi, masjid pada masa Nabi bahkan 1juga berfungsi sebagai pusa pemerintahan ${ }^{18}$

Kedua: Menciptakan persaudaraan baru. Kaum Muslimin yang berhijrah dari Mekah ke Madinah disebut "muhajirin" dan kaum Muslimin penduduk Madinah disebut “anshor”. Kaum Muslimin Mekah yang berhijrah ke Madinah banyak menderita kemiskinan, karena harta benda dan kekayaan mereka ditinggalkan di Mekah, Nabi menciptakan persaudaraan baru antara kaum muhajirin dengan kaum anshor. ${ }^{19} \mathrm{Nabi}$ berhasil membangun sebuah Negara baru yakni Negara Madinah, sehingga secara aklamasi Nabi diangkat sebagai kepala Negara yang diberikan otoritas untuk memimpin dan melaksanakan ketatanegaraan yang telah disepakati bersama. Jadi, di Madinah

\footnotetext{
${ }^{15}$ Wahyu Ilaihi \& Harjani Hefni, Sejarah Dakwah (Jakarta: Rahmat Semesta 2007), 55

16 M.Bahri Ghazali, Dakwah Komunikatif Membangun Kerangka Dasar Ilmu komunikasi Dakwah, (Jakarta: Pedoman Ilmu Jaya, 1997), 1

${ }^{17}$ Jamil Ahmad, Hudred Great Muslims, diterjemahkan oleh Tim penerjemah Pustaka Firdaus dengan judul "serratus Muslim Terkemuka", (Jakarta: Pustaka Firdaus, 2000), 4

${ }^{18}$ Badri Yatim, Sejarah Peradaban Islam, (Jakarta: Rajawali Press, 2008: 26.

${ }^{19}$ A. Syalabi, Sejarah dan kebudayaan Islam (Jakarta: Pustaka Husna, 2003) 103.
} 
beliau seorang penguasa, yang menjalankan kekuasaan politik dan militer dan juga keagamaan 20

Sementara materi dakwah yang Nabi sampaikan juga sangat berbeda, beliau menyesuaikan dengan periode dakwahnya yang terbagi menjadi dua periode, pertama periode Mekah sebelum hijrah, kedua periode Madinah setelah hijrah. Periode sebelum hijrah merupakan masa penyusunan kekuatan dakwah yang dilakukan secara lisan dan ditujukan kepada keluarga Nabi dan warga suku beliau. materi dakwah lebih menitikberatkan pada masalah aqidah keimanan ${ }^{21}$ sehingga ayat-ayat Al-quran yang diturunkan pada periode ini lebih banyak menjelaskan tentang Tauhid yang kita kenal dengan ayat atau surat Makkiyah. Sedangkan periode setelah hijrah ke Madinah periode merupakan masa pembentukan masyarakat yang Islami yang menerapkan ajaran Islam. Materi dakwah pada masa ini tentang masalah kemasyarakatan dan kenegaraan ${ }^{22}$ dan ayat Alquran yang diturunkan berkaitan dengan masalah tersebut dinamakan ayat-ayat Al madaniyah. Oleh karena itu salah satu strategi dakwah rasul adalah kondisoanal, Dakwah beliau yang disampaikan dalam satu tempat belum tentu sama dengan di tempat yang lain.

Sebagaimana telah dicontohkan dari proses dakwah Nabi yang dijelaskan di atas, yang menunjukkan bahwa kondisi sosial, karakter audience, tradisi yang berlaku, sangat menentukan metode dakwah yang akan diterapkan. Hal itu tidak bisa dikesampingkan, karena dengan mengenali beberapa faktor tersebut, seorang da'i bisa menyampaikan materi dakwah dengan metode penyampaian yang bisa disesuaikan dengan kondisi yang ada. Sehingga tujuan dakwah bisa tercapai sesuai dengan yang diharapkan

\section{Menggunakan retorika dakwah yang sopan}

Retorika dakwah adalah seni menyampaikan dakwah melalui akhlak yang baik. jika dianalogikan, mendakwahkan Islam ibarat menghidangkan sebuah makanan. Seberapa pun lezatnya suatu makanan, jika cara menghidangkannya tidak baik maka makanan itu pun enggan dimakan orang. Berbeda halnya dengan suatu makanan yang sederhana, jika ditata sedemikian baik di piring-piring, kemudian dihidangkan dengan senyuman. Orang

\footnotetext{
${ }^{20}$ Bernard Lewis, Yhe Middle East, diterjemahkan oleh Abd. Rachman Abror (Pontianak: STAIN press, 2010), 80 .

${ }^{21}$ Ali Mustafa Yaqub, Sejarah dan Metode Hadis Nabi (Jakarta: Pustaka Fridaus, 2000), 24

22 Ali Mustafa Yaqub, Sejarah dan Metode Hadis Nabi, 25
} 
akan menyantapnya dengan kebahagiaan. Demikianlah retorika dakwah yang diajarkan Islam seperti tercantum dalam Alquran:

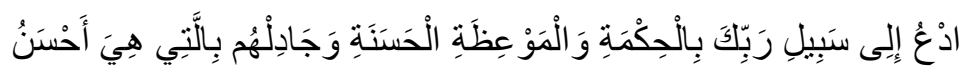

"Serulah (manusia) kepada jalan Rabbmu dengan hikmah (lemah lembut) dan pelajaran yang baik dan bantahlah mereka dengan cara yang baik." (An-Nahl: 125)

Ketika kelembutan telah menghiasi dakwah, maka dakwah Islam akan memberikan pengaruh pada hati-hati kaum Muslimin dan menghasilkan perubahan yang besar di masyarakat. Karenanya jika seorang da'i dalam menyampaikan dakwahnya bersikap arogan dan keras, hal itu sebenarnya justru memperparah suasana. Para jamaah yang sebelumnya sudah bersimpati, justru berpaling disebabkan dai yang kasar dalam berdakwah. Sebagaimana telah ditegaskan oleh Allah dalam firmannya.

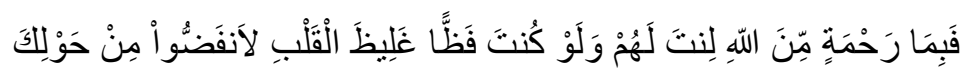

"Maka disebabkan rahmat dari Allah-lah kamu berlaku lemah lembut terhadap mereka. Sekiranya kamu bersikap keras lagi berhati kasar, tentulah mereka akan menjauhkan diri dari dari sekelilingmu." (QS. Ali Imran: 159).

Perintah untuk bersikap lembut kepada semua orang juga ditekankan oleh Allah disaat menegur sikap Nabi. Ketika suatu hari beliau sedang berbicara dengan pembesar Quraisy dengan harapan mereka mau memeluk Islam. Ketika beliau tengah-tengah berbicara, tiba-tiba datanglah seorang yang buta yaitu Abdullah Ibnu Ummi Maktum. Ibnu Ummi Maktum bertanya kepada Nabi tentang sesuatu hal dan mendesak Nabi. Namun Nabi dengan muka kesal berpaling tidak mau melayaninya dan hanya melanyani pembesar Quraish. ${ }^{23}$ Sikap Nabi ini kemudian dikritik Allah dengan menurunkan ayat:

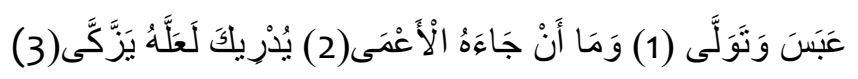

${ }^{23}$ Ali Mustafa Yaqub, Sejarah dan Metode Hadis Nabi, 41 
"Dia (Muhammad) bermuka masam dan berpaling. Karena telah datang seorang buta kepadanya. Tahukah kamu barangkali ia ingin membersihkan dirinya (dari dosa)" (QS. 'Abasa: 1-3).

Ayat di atas menunjukkan perintah untuk tidak bersikap pandang bulu terhadap orang lain. kerena semua sama kedudukannya dihadapan Allah. Sebagaimana disampaikan oleh M. Qurash Shihab, sukses tidaknya dakwah bukan diukur dari banyaknya pendengar, senang tidaknya pendengar. Semakin jama'ah tertawa dan tersedu dalam menangis bukan berarti menunjukkan suksesnya berdakwah. Kesuksesan dakwah adalah membekasnya di hati seseorang para pendengar. Meskipun materinya ringan akan lebih mudah diterima oleh orang dari pada materinya bagus tapi disampaikan dengan nada yang tinggi dan kata yang kasar. Dengan demikian diperlukan kata santun dan lembut, tidak berlebihan dalam menyampaikan materinya, pakaian, tindakan, gestur tubuh. Karena sejatinya seorang da'i tidak sedang berdrama tapi menyampaikn sesuatu yang seharusnya membekas pada orang lain. ${ }^{24}$

Dalam berdakwah gerakan yang berlebihan tidak pernah dilakukan oleh Nabi, begitu pula ketika berkhutbah. Berdasarkan dalam suatu riwayat ketika bisyr bin marwah sedang berkhutbah mengangkat kedua tangannya, tiba-tiba seorang bernama Umaroh Bin Ruaibah berkata "Semoga Allah memburukkan kedua tangan itu karena saya melihat Rasulullah ketika berkhotbah tidak pernah lebih dari berisyarat dengan tangan telunjuk". Dalam hadits ini Nabi memang menunjuk tapi dalam berbagai riwayat beliau tidak menunjuk-munjuk, Nabi hanya berusaha mengangkat ta jari telunjuk tangannya keatas ketika membaca kalimat tauhid sebagai tanda keesaan Allah dan beliau tidak ngacung ngacungkan tangannya ke kanan dan ke kiri. Sama halnya mengangkat kedua tangan ketika berdoa dalam khutbah, para ulama berbeda pendapat seperti Imam Syafi'i dan sebagian ulama Mazhab Syafi'i mengatakan disunnahkan bagi khotib tidak mengangkat tangannya ketika berkotbah. sedangkan Sebagian ulama mazhab Maliki membolehkannya. dengan alasan pada waktu Nabi berkhotbah dan berdoa untuk meminta hujan beliau mengangkat kedua tangan. Dengan demikian mengangkat tangan

${ }^{24}$ Husain Ja'far al-Hadar, 6 Prinsip Dakwah ala Ust Quraish, https://www.youtube.com/watch?v=CXVyZp2wW0, diakses pada 20-02-2020 
yang dibolehkan adalah hanya ketika Khatib sedang berdoa, dan tidak menunjuk-nunjuk atau mengepal tangannya seperti layaknya orang berorasi. 25

\section{Sabar dalam proses dakwah}

Dakwah untuk mengajak kebaikan terkadang harus ditempuh dengan menghadapi berbagai rintangan dan tantangan. Karena itulah, maka dalam berdakwah diperlukan kesabaran dan salah satu kunci sukses seseorang ketika berdakwah adalah sabar, ikhlas tanpa pamrih. Hal ini seperti yang digambarkan dalam al-Qur'an ketika Lukman al-Hakim menasehati anaknya:

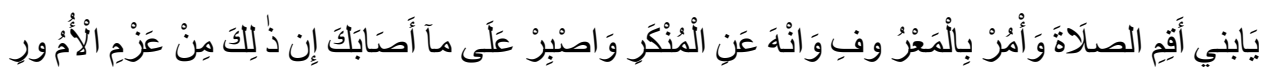

Artinya: "Hai anakku, dirikanlah shalat dan suruhlah (manusia) mengerjakan yang baik dan cegahlah (mereka) dari perbuatan yang mungkar dan bersabarlah terhadap apa yang menimpa

kamu. Sesungguhnya yang demikian itu termasuk hal-hal yang diwajibkan (oleh Allah)." (QS. Luqman (31): 17).

Kesabaran dalam berdakwah juga dicontohkan Nabi, di mana beliau menjadikan kesabaran sebagai perisai yang ampuh dalam menghadapi berbagai tantangan dan hambatan terutama dalam menjalankan misi dakwahnya. Bebagai tantangan dan hambatan yang diperhadapkan kepadanya, misalnya dihina, disakiti perasaannya, dizalimi, baik dengan perbuatan maupun dengan perkataan dan lain sebagainya. Namun hal itu semua tidak menyurutkan semangat perjuangan. Jika seandainya Nabi tidak memiliki sifat penyabar, maka kemungkinan besar misi yang dijalankan tidak mencapai kesuksesan. ${ }^{26}$

Sabar dalam proses berdakwah juga berarti bertahap atau pelan-pelan dalam menyampaikan materi dakwah. Tidak bisa langsung memaksa orang lain untuk berubah menjadi lebih baik. Sebagaimana ketika Allah memberikan tahapan pengharaman minum khomer. Awalnya khamar dibolehkan "Dan dari buah korma dan anggur, kamu buat minuman yang memabukkan dan rezeki yang baik. Sesunggguhnya pada yang demikian

\footnotetext{
25 Ali Mustafa Yaqub, Haji Pengabdi Setan (Jakarta: pustaka Firdaus, 2006), 126.

${ }^{26}$ Syofrianisda, Konsep Sabar Dalam Al-Qur'an Dan Implementasinya Dalam Mewujudkan Kesehatan Mental. HIKMAH: Jurnal Pendidikan Islam Vol. 6, No. 1 Januari - Juni 2017
} 
itu benar-benar terdapat tanda (kebesaran Allah) bagi orang yang memikirkan." 27 Kedua: Turun ayat untuk menjauhkan diri dari khamar karena mudaratnya lebih besar dibanding maslahatnya "Mereka bertanya kepadamu tentang khamar dan judi. Katakanlah: "Pada keduanya terdapat dosa yang besar dan beberapa manfaat bagi manusia, tetapi dosa keduanya lebih besar dari manfaatnya." 28 Ketiga: Turun ayat untuk melarang khamar pada satu waktu, dibolehkan pada waktu lainnya "Hai orang-orang yang beriman, janganlah kamu shalat, sedang kamu dalam keadaan mabuk, sehingga kamu mengerti apa yang kamu ucapkan." ${ }^{29}$ Keempat: Terakhir khamar diharamkan secara tegas "Hai orang-orang yang beriman, sesungguhnya (meminum) khamar, berjudi, (berkorban untuk) berhala, mengundi nasib dengan panah, adalah termasuk perbuatan syaitan. Maka jauhilah perbuatan-perbuatan itu agar kamu mendapat keberuntungan."30

Memberi tahapan dalam berdakwah juga pernah dilakukan Nabi Muhammad saw ketika mengutus salah satu sahabatnya yang bernama Mu'āż bin Jabāl untuk berdakwa di negeri yaman. Pada tahun 10 Hijriyah, menjelang Haji wada' sekitar empat bulan sebelum wafatnya Rasulullah saw. Mu'āż bin Jabāl tidak di tugaskan untuk tidak mengajarkan agama islam secara sekaligus, melainkan dengan cara bertahap, berangsur-angsur dan tanpa adanya paksaan. ${ }^{31}$

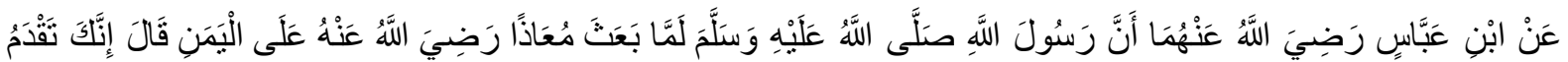

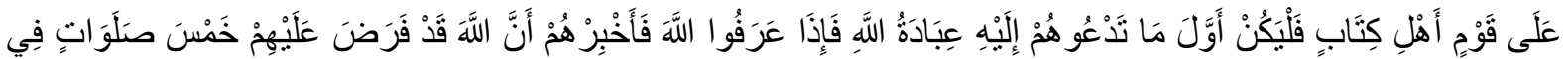

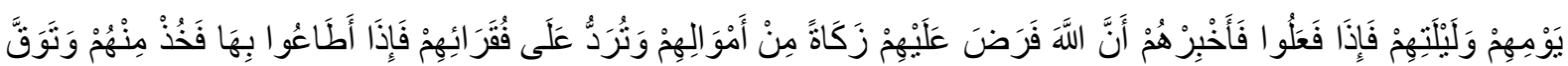

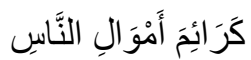

Dari ibnu Abbās ra. Berkata: sesungguhnya Rasulullah saw bersabda: Beliau mengutus Mu'āż ra. Ke yaman. Beliau bersabda: sesungguhnya kami mendatangi masyarakat ahli kitab, maka hendaknya yang pertama kali ajaran yang kamu serahkan kepada mereka adalah bertauhid kepada Allah. Lalu jika mereka mengenang Allah, lalu beritahukan mereka bahwa Allah telah mewajibkan shalat kepada mereka lima kali sehari semalam, lalu apabila mereka sudah

${ }^{27}$ QS. An-Nahl: 67

${ }^{28}$ QS. Al-Baqarah: 219

${ }^{29}$ QS. An-Nisaa: 43

${ }^{30}$ QS. Al-Maidah: 90

31 Jalaluddīn 'Abdurraḥmān as-Suyūṭi, al-Luma' fĩ asbābil Wurūdil hadīs, (Beirut: Dār Iḥya' at-Tūras al-'Arabi, 2001) hlm 455. 
melaksanakannya maka beritahukanlah kepada mereka bahwa Allah mewajibkan kepada mereka membayar zakat hartanya, dan zakat itu di berikan kepada fakir-miskin di antara mereka. Kemudian apabila mereka telah mematuhinya maka terimalah dari mereka, berhatihatilah jangan sampai kamu mengambil harta kesayangan mereka"32

Tahapan dalam proses menyampaikan dakwah juga tergambar dalam sejarah turunnya al-Qur'an. Allah SWT dalam menyampaikan wahyu kepada Nabi Muhammad juga melalui proses yang panjang. Al-Qur'an secara keseluruhan menurut syeikh al-khudhari adalah 22 tahun 2 bulan 22 hari. Yang kemudian dibulatkan menjadi 23 tahun. 33 yang terdiri dari 114 surat, 30 juz. Susunan al-Qur'an ditentukan oleh Allah dengan cara tawqifi, tidak mengggunakan metode-metode sebagaimana metode-metode penyusunan buku ilmiah. Buku-buku ilmiah yang membahas satu masalah, selalu menggunakan satu metode tertentu dan dibagi dalam bab-bab dan pasal pasal. Metode ini tidak terdapat di dalam alQur'an, yang di dalamnya banyak persoalan induk silih berganti diterangkan. 34 Ibn Abbas (w. $68 \mathrm{H}$ ), seorang ilmuwan terkemuka di antara sahabat rasul mempertegas bahwa alQur'an diturunkan ke langit terbawah (bait al-“izzah) dalam satu malam yang kemudian diturunkan secara bertahap sesuai dengan keperluan 35

Tujuan al-Qur'an diturunkan secara bertahap untuk memenuhi tuntunan situasi dan lingkungan yang ada. Perjuangan Nabi yang tidak mengenal lelah untuk mengajak, mengajar dan menyebarkan ajaran Islam, diharapkan agar umatnya menjadi umat yang beraqidah kuat, baik, sabar, harmonis sehingga terarah secara sistematis di bawah panjipanji Islam. ${ }^{36}$ Sementara berlahan-lahan dan bertahap ketika menyampaikan dakwah tujuannya tidak lain agar mudah difahami, dan juga mudah diamalkan.

\section{Berdakwah tanpa menggunakan kekerasan}

Sejarah kehidupan Nabi Muhammad SAW mengajarkan pada kita bahwa kesuksesan Nabi dalam menyampaikan misi dakwahnya adalah sikap pribadinya yang anti

${ }^{32}$ Muhammad bin Ismail Al Bukhari, Shahih Bukhari, (Istambul: Dār at-Tibā'ah al- 'Āmirah, 2005) hlm 125.

${ }^{33}$ Muhammad al-Khudhari, Tarikh al-Tasyri' al Islam (Dar al-fikr, ttp, 1981), 8.

34 M. Quraish Shihab Shihab, Membumikan al Qur'an: Fungsi peran wahyu dalam kehidupan masyarakat (Bandung: Mizan, Edisi ke-2, cetakan ke 1, 2013)16.

${ }^{35}$ M. M. Al A'zami, Sejarah Teks al Qur'an: dari wahyu sampai kompilasi, Terjemah, (Gema Insani Press, 2005)48.

36 Yusron Masduki, Sejarah Turunnya Al-Qur'an Penuh Fenomenal Muatan Nilai-Nilai Psikologi Dalam Pendidikan, medina-te, vol.16, no.1, juni 2017, 42 
kekerasan. Meskipun Nabi dan para sahabat menghadapi berbagai perlawanan dakwah dari orang Kafir Quraisy, baik itu penyiksaan fisik maupun propaganda busuk untuk menyudutkan Islam dan kaum Muslimin, dengan sabar Nabi terus berdakwah menegakkan agama Allah SWT tanpa kekerasan.

Hal ini seperti tergambar dalam sejarah dakwah beliau, di mana ketika beliau menjadi pemimpin di Madinah beliau menjumpai banyak warganya yang beragama Yahudi/Nasrani. Kehidupan keagamaan yang beragam tersebut merupakan kenyataan yang tidak bisa dipungkiri oleh beliau. Dalam konteks seperti ini beliau mengajarkan prinsip-prinsip kehidupan bersama. Prinsip-prinsip itu berisi kontrak sosial antara anggota masyarakatnya dan kemudian dituangkan dalam bentuk perjanjian yang dikenal sebagai “Piagam Madinah”. ditulis pada tahun 623 M atau tahun ke-2 H. Di antara perjanjian paling penting adalah sebagai berikut:

Pertama: Kaum Muslimin dan kaum Yahudi hidup secara damai, bebas memeluk dan menjalankan ajaran agamanya masing-masing. Kedua; Orang-orang Yahudi berkewajiban memikul biaya mereka sendiri, dan kaum Muslimin wajib memikul biaya mereka sendiri. Ketiga; Apabila salah satu pihak diperangi musuh, maka mereka wajib membantu pihak yang diserang. Keempat; Di antara mereka harus saling mengingatkan, saling berbuat kebaikan, saling mencegah kejahatan. Kelima; Kaum Muslimin dan Yahudi wajib saling menolong dalam melaksanakan kewajiban untuk kepentingan bersama. Keenam; Bumi Yastrib menjadi tanah suci karena naskah perjanjian ini. Ketujuh; Nabi Muhammad adalah pemimpin umum untuk seluruh penduduk Madinah. Bila terjadi perselisihan di antara kaum Muslimin dengan kaum Yahudi, maka penyelesaiannya mdikembalikan kepada Nabi sebagai pemimpin tertinggi di Madinah. ${ }^{37}$

Tuntunan dakwah secara ramah juga dijelaskan dalam Al-Qur'an:

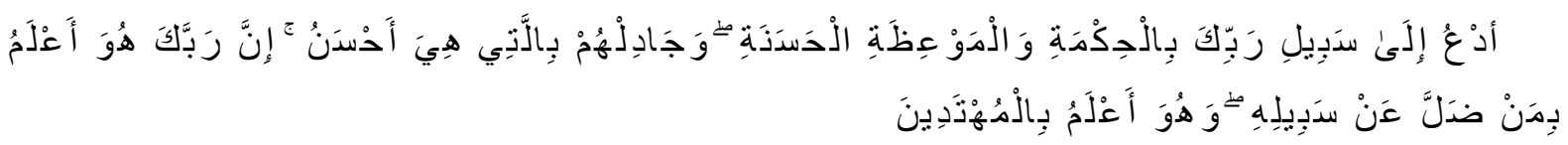

"Serulah mereka ke jalan Tuhanmu dengan hikmah dan nasihat yang baik serta bantahlah mereka dengan cara yang lebih baik. Sesungguhnya Tuhanmu adalah Yang lebih mengetahui siapa yang tersesat dari jalan-Nya dan Yang lebih mengetahui orang-orang yang mendapat petunjuk." (QS An-Nahl [16]: 125)

\footnotetext{
${ }^{37}$ (Wahyu Ilaihi \& Harjani Hefni, 2007: 59).
} 
Jika kita melihat sejarah dakwah Nabi, beliau tidak pernah mengeluarkan kata-kata kasar, apalagi kekerasan dalam menyeru manusia untuk hidup di jalan Allah. Beliau menggunakan tutur kata yang santun dan perilaku yang ramah sebagai metode dakwahnya. Dengan metode yang tanpa kekerasan tersebut dakwah Nabi meraih sukses. Sehingga dalam waktu relatif singkat Islam bisa diterima dan diterapkan dalam seluruh aspek kehidupan masyarakat di jazirah Arab saat itu.

\section{Relevansi jihad dengan tujuan dakwah}

Hingga saat ini, jihad bagi para kaum ekstremis dipahami sebagai perang fisik dengan mengangkat senjata (baca: perang). Hal itu menjadi dasar legitimasi agama untuk melakukan kekerasan sehingga muncul radikalisme agama. Problem tersebut muncul karena kesalahan memaknai jihad. ketika memahami makna "jihad". Hanya satu kata “ berjuang dijalan Allah SWT dengan melawan musuh Allah SWT" dimana-pun dan sampai kapanpun. Siapa-pun orangnya, jika teologinya tidak sesuai dengan teologi mereka, dikategorikan “kufur”. Pancasila dianggap “Thogut”, demokrasi juga di anggab "thogut”, karena bukan dari Al-Quran dan Rosulullah SAW”. Siapa yang “berjihad” kemudian mati, maka mereka berhak masuk surga tanpa hisab. Mereka-pun yakin, bahwa "jihad" itu sebagai bentuk pengabdian diri, bentuk cinta kepada Allah SWT dan Rosulullah SAW. Siapa yang meninggal, maka kelak akan langsung masuk surga yang di dalamnya ada bidadari cantik yang telah menantinya. 38

Kelompok radikalisme melihat bahwa ajaran agama Islam di Indonesia masih tercampur dengan budaya Hindu, Budha, bahkan sudah terkontaminasi dengan Yahudi dan Nasrani, sehingga perlu adanya pemurnian agama. Semua itu hanya bisa dirubah dengan cara "jihad" bukan hanya sekedar dakwah. Jihad menurut mereka ialah sebuah perjuangan menegakkan agama Allah SWT melawan orang-orang kafir (musuh-musuh Allah SWT). Bahkan orang-orang muslim yang menghalangi terwujudnya negara Khilafah Islamiyah atau mendirikan Negara Islam (Daulah Islamiyah) juga dikategorikan musuhnya. Siapa-pun yang tidak se-iman dan sejalan di anggab sebagai musuhnya.

\footnotetext{
${ }^{38}$ Abdul adzim irsad, Jihad Dalam Pandangan Radikalisme https://www.kompasiana.com/www.tarbawi.wodrpress.com/54f67a0fa33311b07d8b4d2b/jihad-dalampandangan-radikalisme, 19-02-2010, 20:07.
} 
Orang muslim yang sudah menjalankan rukun Islam, tidak dipandang sebagai seorang muslim jika mereka tetap melakukan Bid'ah (tahlilan, istighosahan, dan maulidan, ziarah kubur). Siapa-pun orangnya, dan apa-pun agamanya, meskipun ia orang Islam jika berkerja sama dengan Amerika, maka halal darahnya untuk ditumpahkan.

Menurut Ali Mustafa Yaqub ada beberapa karakteristik radikalisme diantaranya adalah.

1. Fanatik terhadap pendapat sendiri dan tidak mengakui pendapat orang lain. Orang yang fanatik biasanya terbelenggu dengan pendapatnya sendiri, ia tidak mau tahu bahwa pihak lain mempunyai pendapat lain yang bisa jadi lebih baik daripada pendapatnya. Orang yang fanatik selalu meyakini pendapatnya lah yang benar sedangkan pendapat lain yang sama. sementara andaikan pendapat tersebut berdasarkan ijtihad maka mereka harus menyadari bahwa ijtihad itu bisa jadi benar bisa jadi salah sebagaimana pendapat orang lain.

2. Terikat dengan amalan yang sangat kaku. Orang yang mengamalkan amalan yang kaku akan sangat terikat, la juga memaksa orang lain untuk mengikuti jejaknya yang dianggapnya paling benar.

3. Kasar dalam ucapan dan perbuatan. Kebiasaan selanjutnya adalah perilaku yang kasar baik dari ucapan ataupun tindakan kata kera dan tindakan yang anarkis seakan menjadi ciri khas dari golongan mereka.

4. Ssering negatif thinking. selalu berprasangka buruk atau berpikiran negatif sehingga mereka sering mencari-cari kesalahan orang lain tanpa mau memperdulikan kebaikannya apabila kesalahan yang dicari itu tidak ada la pun tidak segan-segan membuat kesalahan untuk difitnahkan kepada orang.

5. Mudah mengkafirkan orang lain. ketika usaha mereka tidak berhasil, terkadang mereka menempuh cara lain dengan mengkafirkan orang lain yang tidak sepaham bahkan ia berani berfatwa orang lain itu halal darahnya dan boleh dibunuh. hanya karena melihat orang lain berbuat maksiat mereka sudah berani mengkafirkannya sementara dalam Islam, Rasul sendiri justru melarang menuduh kafir kepada sesama muslim bahkan beliau mengancam apabila yang dituduh itu bukan kafir justru yang menuduh lah yang menjadi kafir39

39 Ali Mustafa Yaqub, Haji Pengabdi Setan ( Jakarta: Pustaka Firdaus, 2006),43. 
Ada beberapa faktor penyebab yang melatar belakangi tindakan radikalisme, anarkisme, dan terorisme. Pertama; pandangan yang sempit terhadap hakikat agama. Kedua, Mamengikuti paham lahiriyah atau paham tekstual yang tidak mempertimbangkan konteks sama sekali. Ketiga, terbatas dalam mempelajari agama artinya mereka belajar agama dari satu aliran saja. Keempat, pengetahuannya kurang mendalam tentang sejarah dari kehidupan Nabi. ${ }^{40}$ Beberapa factor penyebab ini kemudian mengakibatkan mereka (kaum radikal) selalu bersikap keras terhadap kelompok lain, dan merasa sudah berpegang teguh pada Al-Quran dan Hadis, walaupun sebenarnya mereka tidak faham bentul makna dan pesan Al-Quran.

Dalam Alquran memang banyak ayat yang berbicara tentang perang dan banyak juga ayat yang berbicara tentang damai, begitu juga dalam hadis Nabi. Harusnya ayat dan hadis Nabi tentang perang digunakan dalam keadaan perang. dan menggunakan ayat dan hadits tentang damai untuk keadaan damai. Jika ayat dan hadits tentang perang digunakan untuk keadaan damai atau jika ayat Alquran dan hadis tentang damai digunakan untuk keadaan perang, inilah yang menimbulkan kesalahpahaman. Misalnya, ketika Allah berfirman

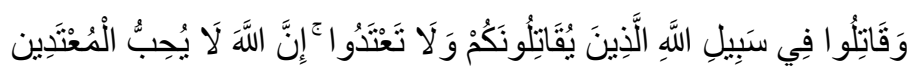

Dan perangilah di jalan Allah orang-orang yang memerangi kamu, (tetapi) janganlah kamu melampaui batas, karena sesungguhnya Allah tidak menyukai orang-orang yang melampaui batas.

Ayat ini memang memerintahkan untuk berperang melawan musuh. Namun perintah ini tidak secara mutlak memperbolehkan membunuh semua orang. hanya non muslim yang memerangi muslim saja yang boleh di perangi. Berdasaarkan sejarah Nabi, Islam membagi tiga kategori orang non muslim.

1. kafir Harbi yaitu non muslim yang memerangi kaum Muslimin

2. kafir Musta'man yaitu non muslim yang tinggal sementara di negara Islam, karena ada urusan bisnis, kepentingan diplomatik, belajar dan lainnya.

\footnotetext{
${ }^{40}$ Ali Mustafa Yaqub, Haji Pengabdi Setan, 45.
} 
3. Kafir dzimmi yaitu non muslim yang menetap bersama orang muslim, dan memiki perjanjian berdamai dengan orang muslim.

Dari ketiga kategori non muslim di atas, yang boleh diperangi adalah hanya kafir harbi, orang non muslim yang memang memerangi orang muslim. Jika tidak memerangi maka tidak diperkenankan menyerang atau melawan mereka. Dalam sejarah Islam peperangan yang terjadi antara orang muslim dengan orang kafir, penyebabnya bukan karena perbedaan agama, peperangan tersebut disebabkan alasan lain. Hal ini menunjukkan bahwa perbedaan agama bukan penyebab terjadinya perselisihan antara penganut agama. Jika memang karena perbedaan agama menjadi alasan diperbolehkannya membunuh penganut agama lain, mengapa Nabi tidak membunuh mertuanya Nabi yang memeluk agama Yahudi. Bapak dari shofiyah istri Nabi tersebut bernama Huyay bin Akhtab, pemimpin bani Quraidhah yang tidak masuk Islam meskipun putrinya shofiyah masuk Islam.

Kendatipun perang tidak dapat dielakkan, tetap ada etika yang harus diindahkan. Antara lain: dilarang membunuh orang tua, wanita, atau anak kecil, begitu juga dilarang menebang pohon atau meruntuhkan bangunan atau membumi hanguskan daerah. AlQur'an juga menekankan bahwa kalau ada ikatan perjanjian antara kaum Muslim dengan selain mereka, perjanjian itu harus dihormati. Kalau pun ada tanda pengkhianatan dari mereka, maka sebelum mengambil tindakan harus disampaikan terlebih dahulu kepada mereka bahwa perjanjian dibatalkan. Hal itu berdsarkan firman Allah.

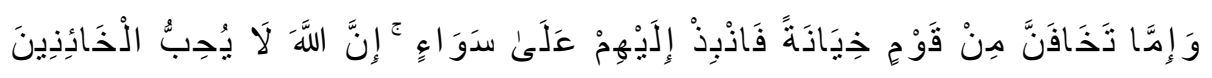

Dan jika kamu khawatir akan (terjadinya) pengkhianatan dari suatu golongan, maka kembalikanlah perjanjian itu kepada mereka dengan cara yang jujur. Sesungguhnya Allah tidak menyukai orang-orang yang berkhianat.

Dengan demikian, ketika terma "jihad” yang dijadikan prinsip oleh orang radikal dianggap sudah sesuai dengan ajaran Islam, maka hal ini jelas tidak terbukti sama sekali. Sebagaimana telah dipaparkan di atas, bahwa "jihad" Nabi dengan tujuan dakwah tidak ada yang menggunakan sikap anarkis atau kekerasan sama sekali. Hal ini nampak ketika tak satupun perang yang dipimpin oleh Nabi disebabkan karena beda agama apalagi beda pendangan. Nabi hanya memerangi orang kafir yang mengkhianati perjanjian damai, atau 
yang berbuat curang dan yang menyerang orang muslim. Orang kafir yang tidak menyerang dan berdamai dengan orang muslim tetap dibiarkan aman.

Kalaupun Nabi terpaksa harus berperang, tetap ada etika yang dipegang oleh Nabi, seperti memberikan penawaran perdamain sebelum berperang. Kendatipun harus berperang namun tetap tidak menimbulkan kerusakan bangunan, pohonan, dan daerah. Nyawa anak kecil, orang tua, perempuan tetap dilindungi dan tidak boleh dibunuh. Berbeda dengan praktek "jihad" kaum radikal dengan cara bom bunuh diri, di mana korbannya tak pandang bulu, semua orang dibunuh dan diserang. Bangunan, tanaman, dan fasilitas umum semua dihancurkan tanpa terkecuali. Dengan demikian "jihad” yang dipegang teguh oleh kaum radikal jelas sangat bertentangan dengan "jihad” yang sudah dicontohkan Nabi. Sementara terorisme yang mereka lakukan selama ini tidak lain adalah salah satu bentuk kejahatan, seperti yang ditegaskan oleh Ali Mustafa Yaqub bahwa terorisme adalah sebuah kriminalitas yang tidak memiliki dasar dari agama atau kebangsaan. terorisme dapat datang dari siapa saja dan karenanya mengkaitkan terorisme dengan agama tertentu justru akan menambah masalah yang tidak dapat diselesaikan. ${ }^{41}$

\section{PENUTUP}

Nabi Muhammad adalah teladan bagi para dai dalam menyebarkan nilai-nilai Islam yang rahmatan lil alamin, dengan penuh kegigihan, rendah hati, dan kesabaran. Dakwah dengan penyampaian yang lemah lembut, dan ramah terhadap realitas sosial yang ada, merupakan ajaran Nabi yang berpijak pada wahyu Allah. Oleh karena itu, para pendakwah tidak hanya dituntut mempelajari sumber-sumber ajaran lalam, tetapi juga harus memahaminya secara komprehensif melalui berbagai disiplin ilmu yang kemudian diintegrasikan dengan karakter dan kondisi sosial masyarakat. Jika dakwah disampaikan dengan cara anarkis atau kasar, hal itu menunjukkan bahwa minimnya pengetahuan dan penghayatan tentang ajaran Islam. Karena sejatinya tidak ada satu agama pun di dunia ini yang melegalkan atau mengajarkan tindakan anarkis. Agama Islam justru menjadi sumber utama inspirasi kebahagiaan dan kedamaian. Dakwah sejatinya adalah mengajak bukan mengejek, merangkul bukan memukul, menyentuh bukan menyinggung

\footnotetext{
${ }^{41}$ Ali Mustafa Yaqub, Teror di Tanah Suci (Tangerang: Maktabah Darus sunnah, 2016), 30.
} 
Di era modern seperti saat ini, di tengah pesatnya perkembangan teknologi dan ilmu pengetahuan yang semakin canggih, justru dakwah seperti yang dicontohkan Nabi SAW masih sangat relevan untuk dijadikan acuan. Metode dan langkah-kangkah berdakwah yang sudah ditempuh oleh Nabi seharusnya menjadi tolak ukur yang bisa diteladani oleh para da'i dalam menyampaikan dakwah. Metode dakwah selain yang dicontohkan Nabi -yang tidak mengusung prinsip rahmatan lil alamin- adalah metode yang tidak layak dijadikan parameter dan dapat bermuara pada kegagalan dan perpecahan.

\section{REFERENSI}

A. Syalabi, Sejarah dan kebudayaan Islam. Jakarta: Pustaka Husna, 2003.

Ahmad, Jamil. Hudred Great Muslims, diterjemahkan oleh Tim penerjemah Pustaka Firdaus dengan judul “serratus Muslim Terkemuka”. Jakarta: Pustaka Firdaus, 2000.

Al A'zami, M. M. Sejarah Teks al Qur'an: dari wahyu sampai kompilasi, Terjemah. Gema Insani Press, 2005.

Al-Bukhari, Muhammad bin Ismail Shahih Bukhari. Istambul: Dār at-Tibā’ah al-‘Āmirah, 2005.

al-Dhahabi>, Muh\{ammad ibn Ah\{mad ibn 'Uthma>n. Dhikru Man Yu’tamad Qauluhu fi alJarh\{ wa al-Ta'di>l. Kairo: al-Matbu'ah al-Islamiyyah, tth.

al-Hadar, Husain Ja'far. 6 Prinsip Dakwah ala Ust Quraish, https://www.youtube.com/watch?v=C-XVyZp2wWo, diakses pada 20-02-2020

al-Khati>b, Muh\{ammad 'Aja>j. Us\{u>l al-H\{adi>th ‘Ulu>muhu wa Mus\{t\{ala>h\{uhu. Bairu>t: Da>r al-Fikr, 1975.

al-Khudhari, Muhammad. Tarikh al-Tasyri' al Islam. Dar al-fikr, ttp, 1981.

al-Naisa>buri>, Muslim ibn al-H\{ajja>j ibn Muslim S\{ah\{ih\{ Muslim. Bairu>t: Da>r al-Ih\{ya>' al-'Arabi>, tth.

al-Nawa>wi>, 'Abu> Zakariya> Syarh\{ al-Nawa>wi> 'Ala>S\{ah\{i>h\{ Muslim. Mesir: alMaktabah al-Mis\{riyyah, 1924. Schimmeel, Annemarie. Dan Muhammad adalah Utusan Allah. Bandung: Mizan, 2000.

al-Ra>zi>, 'Abd al-Rahman ibn 'Abi> Ha>tim 'Abu> Muh\{ammad. Al-Jarh\} wa al-Ta'di>l. Bairu>t: Da>r al-Fikr, tth.

al-Shobuni, Muhammad Ali. rawa'i Al Bayan tafsir ayat Al Ahkam Min Alquran .Damaskus: Maktabah Al Ghazali, 1977 M. 
as-Suyūți, Jalaluddīn 'Abdurraḥmān. al-Luma' fĩ asbābil Wurūdil hadīs. Beirut: Dār lḥya' atTūras al-‘Arabi, 2001.

Ghazali, M.Bahri., Dakwah Komunikatif Membangun Kerangka Dasar Ilmu komunikasi . Jakarta: Pedoman Ilmu Jaya, 1997.

Irsad, Abdul adzim. Jihad Dalam Pandangan Radikalisme https://www.kompasiana.com/www.tarbawi.wodrpress.com/54f67aofa33311bo7d 8b4d2b/jihad-dalam-pandangan-radikalisme, 19-02-2010, 20:07.

Ismail, M. Syuhudi. Metodologi Penelitian Hadis Nabi. Jakarta: Bulan Bintang, 2007.

'Itr , Nu>r al-Di>n, Manhaj al-Naqd fi ‘Ulu>m al-Hadi>th. Damaskus: Da>r al-Fikr, 1399 H.

Lapidus, Ira, A History of Islamic Sicieries, diterjemahkan oleh Ghufron A. Mas'adi, dengan judul "Sejarah Sosial Ummat Islam". Jakarta: Raja Grafindo, 1999.

Lewis, Bernard. Yhe Middle East, diterjemahkan oleh Abd. Rachman Abror. Pontianak: STAIN press, 2010.

Masduki, Yusron. Sejarah Turunnya Al-Qur'an Penuh Fenomenal (Muatan Nilai-Nilai Psikologi Dalam Pendidikan). Medina-Te, VOL.16, NO.1, Juni 2017.

Shihab, M. Quraish Shihab. Membumikan al Qur'an: Fungsi peran wahyu dalam kehidupan masyarakat. Bandung: Mizan, Edisi ke-2, cetakan ke 1, 2013.

Syofrianisda, Konsep Sabar Dalam Al-Qur'an Dan Implementasinya Dalam Mewujudkan Kesehatan Mental. HIKMAH: Jurnal Pendidikan Islam Vol. 6, No. 1 Januari - Juni 2017

Wahyu Ilaihi \& Harjani Hefni, Sejarah Dakwah. Jakarta: Rahmat Semesta 2007.

Yaqub, Ali Mustafa. Sejarah dan Metode Dakwah Nabi. Pejaten: Pustaka Firdaus, 2000.

Teror di Tanah Suci. Tangerang: Maktabah Darus sunnah, 2016.

Haji Pengabdi Setan. Jakarta: pustaka Firdaus, 2006.

Yatim, Badri. Sejarah Peradaban Islam. Jakarta: Rajawali Press, 2008. 